\title{
BREEDING RAPTOR CENSUS IN Grand Teton National Park, 2001
}

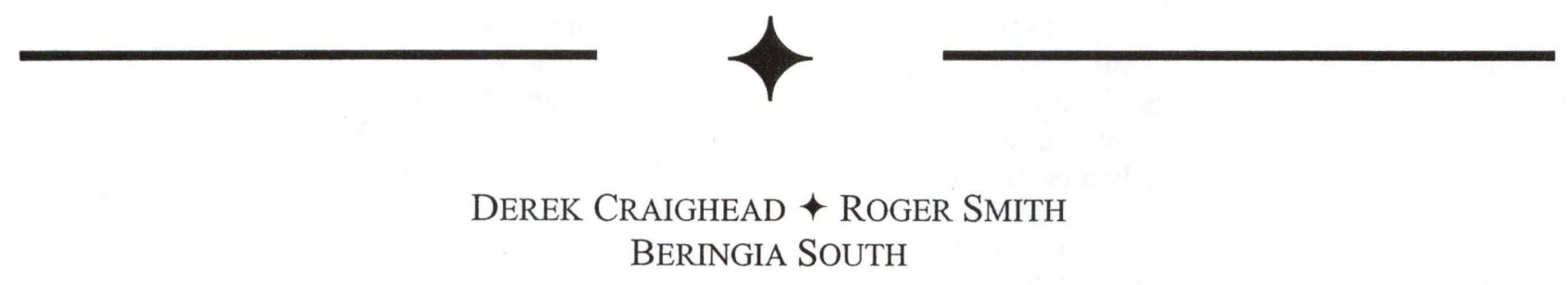

\begin{abstract}
$\downarrow \quad$ ABSTRACT
We documented abundance and diversity of raptors in a relatively undisturbed landscape in Grand Teton National Park, Wyoming, from February through August 2001. We located a total of 38 nesting pairs / $31.1 \mathrm{~km}$, and a total of 8 raptor species. The American kestrel (Falco sparverius) and the Common raven (Corvus corax) were the two most abundant species on the study area. In this study, we considered Common ravens as an ecological and trophic level equivalent of raptors. Five of the eight species migrate, and two of the eight species are known neotropical migrants. The mean number of young fledged for all species was 1.9 (range $=0.2$ to $3.1, \mathrm{SD}=1.3$ ). We located the territory but not a nest for three Great horned owl (Bubo virginianus) pairs. Low precipitation and warm temperatures characterized weather during the last two years. Effects of weather conditions and human disturbance on raptor abundance within the study area were examined.
\end{abstract}

\section{$\downarrow \quad$ INTRODUCTION}

This report summarizes monitoring and research efforts for raptors on the Blacktail Butte study area, Grand Teton National Park (GTNP) for the 2001 field season. We present data on abundance and diversity of raptors, level of search effort, estimates of human use and disturbance in the study area, and weather conditions during the breeding season. Previous raptor census data on Blacktail Butte was recorded in 1947, 1975, and 1987. Our objectives were to census all raptor populations in the Blacktail Butte study area in 2001 and, make available this data for future long-term monitoring and analyses of raptor population dynamics on this study area.

For many avian species, particularly raptors, little long-term knowledge about population trends exists. Although many species and populations of North American birds have undergone declines in abundance in recent decades, the extent and causes of such changes are much debated (Martin and Finch 1995, Rappole 1995, Latta and Baltz 1997, Brawn et al., 1998). While many studies have considered effects of habitat fragmentation and other humanmediated changes, relatively few data exist on the degree to which bird populations are changing, or have changed, in relatively undisturbed or unfragmented habitats. Long-term quantitative data on raptor populations in undisturbed habitats, such as those found in National parks, are rare. Information from such sites can be useful for understanding what factors determine bird abundance locally and for providing a control against which to compare population changes occurring in more humaninfluenced habitats. 


\section{STUDY AREA}

The study area (Figure 1) is a $31.1 \mathrm{~km} 2(12$ $\mathrm{mi2}$ ) area located in northwestern Wyoming within GTNP (43 40N, $11043 \mathrm{~W})$. This study area used in three previous raptor studies: 1947 (Craighead and Craighead 1956), 1976 (Craighead and Mindell 1981) and 1987 (Craighead et al. 1987). GTNP is situated in a high mountain valley that is surrounded by the Teton range to the west, the Gros Ventre mountains to the east, and the Yellowstone plateau to the north. Within the study area, vegetation, climate and landscape features have been described by Craighead and Craighead (1956), and Dunk et. al. (1996). Elevation of nests within the study area ranged from $1934 \mathrm{~m}$ to $2164 \mathrm{~m}$. Most of the non-forested area in the study area was in hay production until the mid 1960 's. Currently, $14.6 \mathrm{~km} 2(47 \%)$ of the study area is timbered, and $53 \%(16.5 \%)$ is open sage/shrubland and/or remnant agricultural area that consists mainly of non-native grass (Bromus spp.). Included in the study were three relatively localized human-use areas:1) GTNP headquarters in Moose, Wyoming; 2) Dornan's village which consisted of a restaurant, store, outdoor restaurant, guest cabins, and several retail shops; and 3) the Murie center which consisted of administrative cabins, guest cabins, and established hiking trails.

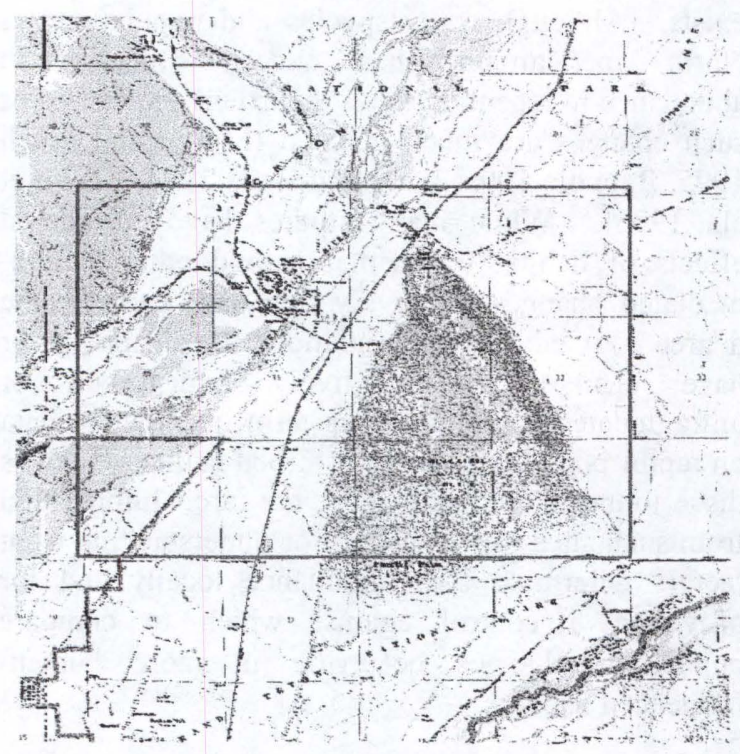

Figure 1. The 31.1 square kilometer study area ne: Moose, Wyoming.

\section{METHODS}

Nesting census-We followed nestsearching methodology used in 1947 (Craighead and Craighead 1956). Our goal was to locate as many occupied nesting areas as possible within the designated study area. From February through August, we repeatedly searched all areas on the study area. We re-visited all nesting territories occupied during 1947 and 1987 census efforts. We did not have nest locations from the 1975 census. We considered a historical nesting area to be vacant if we detected no sign of occupancy by the end of the brood-rearing period. We conducted direct observations of nesting areas from a distance for nest-building activity, prey deliveries or other behaviors that would help pinpoint a nest. Duration of observation sessions ranged from two to eight $h$. All bird movements during each observation session were recorded onto USGS 7.5 minute quadrangle maps. We surveyed for owl nesting areas during predawn and late evening from late February-April to improve detection of nests.

To quantify the effectiveness of our census effort used to locate nesting pairs, we used a hand-held global positioning system (GPS, Garmin Map 12, Garmin Corporation, Olathe, KS) to record total distance, route traveled and total time spent searching each day using the GPS tracking function. Tracks were plotted using the extension Waypoint+ onto topographic maps in Arcview (ESRI, Inc.) to highlight areas to be searched. We used the GPS to map all located nests on to USGS 1:24000 topographic maps.

We used broadcast vocalizations of accipiters and owls to identify active territories throughout the study area. For broadcasting calls, we used a Radio Shack megaphone and digital recordings of both alarm and wail calls. Distance between calling stations varied from 150-300 m depending on openness of terrain.

Nesting success-Terminology used for reporting raptor-monitoring results follows recommendations made by Postupalski (1974). In our analyses of nesting success for buteos and ravens, we included as occupied those nests with fresh green material on the nest edge, and/or nesting areas where two adults were vocal and defensive when we walked into the nesting area. An alternate nest refers to a 
nest structure with fresh greens that is located in close proximity to an occupied nest with birds present, but was not being currently used during the year of observation. In such instances we considered as occupied only one nest. Stick nests were inspected from the ground using binoculars, or with a modified mirror pole (Parker 1972). We located American kestrel nests by: 1) maintaining detailed records of all sightings of adult kestrels during the spring and summer field season and, 2) returning to those areas during the first two weeks of July when the adults were vocal and delivered food to the nestlings. We also used a small mirror and flashlight to inspect number of eggs and/or young in occupied kestrel cavity nests. We visited most nests a maximum of three times to determine occupancy and number of fledglings. We recorded number of eggs laid only for nesting accipiters. In this report, we use the terms nesting pair and occupied nesting area interchangeably.

Prey density estimates-We estimated ground squirrel density in three existing colonies within the study area by stationary visual counts (see Wigglesworth, 2001, Beringia South, Unpubl. data). Ground squirrel colonies were identified and mapped in 2000 (Chalfoun 2000) with the intent of conducting long-term monitoring of ground squirrel population trends. In 2001, count data was collected from colonies O2 (2.32 ha) and S4 (1.27 ha) (see Chalfoun 2000 for details). Results from 2001 ground squirrel density estimates were compared to similar data collected in 2000 .

Climatic changes-As an index to climatic change, we plotted monthly records of average temperatures and precipitation collected from Moose, Wyoming for the periods of 1950-2001 and 19592001 respectively.

Human Disturbance-We quantified human disturbance in and adjacent to the study area by documenting: the number of people we encountered while in the backcountry portion of the study area; visitation rates at the Moose visitor center; the number of raft trip passengers on the Snake River; and the number of enplanements and landings at the Jackson Hole airport. The airport is situated within $2.4 \mathrm{~km}$ of the southwest end of Blacktail Butte, and the majority of commercial and private planes fly directly over or parallel to Blacktail Butte on landings and take-offs. Due to the close proximity of the airport to Blacktail Butte, large commercial planes fly at altitudes of $<300 \mathrm{~m}$ above the Butte during their landing approach, and small private planes fly below this altitude.
Biases-Several potential biases are inherent in conducting a study to determine absolute abundance and density estimates, where such an effort assumes that each nest must be located. Our ability to locate each nesting pair was attributed to both the characteristics of the study area and to search effort. Our study area was relatively small (31 $\mathrm{km}^{2}$ ) and approximately $50 \%$ of this area was forested. The remaining portion was relatively open habitat with little topographic relief and was conducive to direct observations of territorial birds.

Accurate recording of nest occupancy and reproductive success are sensitive to survey timing, duration, and researcher effort. Human disturbance can cause nest failure early in the breeding season and thus underestimate reproductive rates. Census efforts that begin late often miss pairs that failed early and, therefore, may overestimate reproductive rates. A lack of researcher experience and their familiarity with the study area may also provide a source of potential error. However, two individuals (DC, RS) completed most of the nest census effort. One individual (DC) has over 40 years experience hiking on and adjacent to Blacktail Butte, and conducted raptor nest surveys during much of that time. RS has been intensively studying raptors on and adjacent to Blacktail Butte over the past 12 years.

There appears to be inherent problems in all census methods. Raptor census studies comparing both random and non-random sampling methods to estimate raptor abundance have shown practical difficulties or had potential biases for most species under study (see Lehman et al., 1998).

In conclusion, we believe that several factors combine to satisfy the requirements of an accurate nesting census on our study area: 1) relatively small and open study area that was conducive to direct observation of most raptors on the area, 2) the successful use of a GPS tracking capability that allowed us to map and detect areas in need of searching on a daily basis, and 3) trained and experienced field researchers.

\section{$\uparrow \quad$ RESULTS}

Nest census-In 2001, we located 38 occupied raptor nests (Table 1). These 38 nests produced 68 young, an average of 1.9 young/nesting pair or 1.3 young/successful nest (Table 1). Of the total number of fledged raptors on the study area $(n=68)$, kestrels and ravens fledged $44 \%$ and $32 \%$, respectively (Fig. 2). American kestrels, representing 
$36.5 \%$ of the population, was the most abundant nesting raptor on the study area.

\begin{tabular}{|c|c|c|c|c|c|c|c|c|c|}
\hline Species & $\begin{array}{l}\text { No } \\
\text { Pairs }\end{array}$ & $\begin{array}{c}\begin{array}{c}\text { nesting } \\
\text { Pairs }\end{array} \\
\text { Pan }\end{array}$ & $\begin{array}{c}\text { No. sq. } \\
\text { miles } \\
(\mathrm{km}) \text { pair }\end{array}$ & $\begin{array}{l}\text { Succ. } \\
\text { nests }\end{array}$ & $\begin{array}{l}\text { eggs } \\
\text { laid }\end{array}$ & $\begin{array}{l}\text { eggs } \\
\text { hatched }\end{array}$ & $\begin{array}{l}\text { young } \\
\text { fledged }\end{array}$ & $\begin{array}{l}\text { young } \\
\text { fledgel } \\
\text { nesting } \\
\text { pair }\end{array}$ & $\begin{array}{c}\text { young } \\
\text { fledgel } \\
\text { succ } \\
\text { nest }\end{array}$ \\
\hline $\begin{array}{l}\text { Red-tailed Hawk } \\
\text { Buteo }\end{array}$ & 5 & 5 & $2.4(6.2)$ & 1 & $\cdot$ & - & 1 & 0.20 & 1.0 \\
\hline $\begin{array}{l}\text { Buteo jamaicensis } \\
\text { Swainson's Hawk } \\
\text { Buteo }\end{array}$ & 2 & 2 & $6(15.5)$ & 2 & - & - & 3 & 1.5 & 1.5 \\
\hline $\begin{array}{l}\text { Buteo swainsonii) } \\
\text { American Kestrel }\end{array}$ & 15 & 15 & $0.8(2.1)$ & 14 & - & - & 30 & 2.0 & 2.1 \\
\hline $\begin{array}{l}\text { Falco sparverius } \\
\text { Cooper's Hawk }\end{array}$ & 1 & 1 & $12(31.1)$ & 1 & 3 & 2 & 2 & 2.0 & 2.0 \\
\hline $\begin{array}{l}\text { Accipiter cooperii } \\
\text { Sharp-shinned Hawk } \\
\text { Accipiter striatus }\end{array}$ & 1 & 1 & $12(31.1)$ & 1 & 4 & 4 & 4 & 4.0 & 4.0 \\
\hline $\begin{array}{l}\text { Accipiter striatus } \\
\text { Bald Eagle } \\
\text { H. leucocephalus }\end{array}$ & 1 & 1 & $12(31.1)$ & 1 & - & - & 1 & 1.0 & 1.0 \\
\hline $\begin{array}{l}\text { H. leucocephalus } \\
\text { Great horned Owl }\end{array}$ & 3 & - & - & - & & - & & & \\
\hline $\begin{array}{l}\text { Bubo virginianus } \\
\text { Common Raven } \\
\text { Corvus corax }\end{array}$ & 13 & 13 & $0.9(2.4)$ & 7 & . & . & 22 & 1.7 & 3.1 \\
\hline Total & 41 & 38 & $\begin{array}{l}0.31 \\
(0.82)\end{array}$ & 27 & $\cdot$ & - & 68 & $\begin{array}{c}1.9 \\
(s d=1.3)\end{array}$ & 1.3 \\
\hline
\end{tabular}

Figure 2. Density of raptors in a $31.1 \mathrm{~km}^{2}$ study area, Grand Teton National Park, 2001. $\mathrm{N}=41$ nests

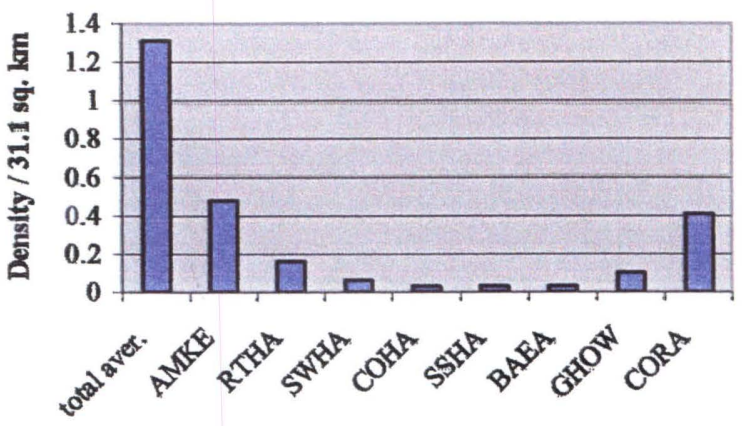

Habitat preferences-We located one pair of kestrels in a nest box (Choinard). We observed one adult pair of kestrels actively feeding three young along the east side of Blacktail Butte, but we did not locate the nest. Fourteen of $15(93 \%)$ kestrel nests were situated in or adjacent to open habitats, either in a narrow strip of cottonwoods such as along Ditch creek, or in a lone tree. One pair nested in a semiopen forest on the southwest side of Blacktail Butte. Kestrels nested in three tree species (Appendix 1). Seven of $15(46 \%)$ kestrels nested in a live tree, however, each cavity was situated in a dead portion of that nest tree. Kestrels fledged between July 12 and July 30 (mean July 21, n=15, Appendix 2).

Common ravens were the second most numerous species, forming $31.7 \%$ of the population. Common ravens nested in four tree species (Appendix 1), and nests were generally located in isolated stands of trees, lone trees, or on edges of larger forest stands. Throughout the summer, we observed numerous ravens that were not nesting in the area. These were most likely unpaired birds, or pairs that nested outside our study area and used the study area to forage. Ravens fledged between June 12 and June 24 (mean June 17).
Red-tailed hawks (Buteo jamaicensis) were the third most numerous species, forming $12.2 \%$ of the population. Red-tailed hawks nested in three tree species (Appendix 1), and nests were located in habitats ranging from dense conifer stands on relatively steep hillsides, to a lone cottonwood tree situated in open sageflat/shrubland.

Both accipiter nests were found in dense, mature spruce stands in the Snake River bottom. Accipiter nesting areas were located by identifying plucking posts and from adult vocalizations during May, and observing prey deliveries to the nest in July. Both accipiter species fledged young during the first week of August. The Bald eagle nest was situated adjacent to the Snake River in the southwestern portion of the study area.

Species that we observed on the study area but did not locate nests for included: Northern goshawk (Accipiter gentillus), Long-eared owl (Asio otus), and Great horned owl (Bubo virginianus). From May through August, we observed a single adult goshawk on eight different occasions along the Snake River bottom in the southwest portion of the study area. The longest sighting was when the bird flew with prey and perched adjacent to the bridge in Moose. This bird immediately ate the prey, and then flew to the west and out of view. All other sightings of a goshawk were relatively short. Throughout this area, we played taped calls early in the nesting season then switched to wail calls at the time of fledging. We heard no goshawks respond to our taped calls. We sighted two adult Long-eared owls in a dense conifer forest on the southeast portion of Blacktail Butte. We were unable to locate these birds during four subsequent survey efforts, nor did we receive a response to taped calls. We observed and heard a pair of Great horned owls hooting in late February in the Snake River bottom. Two Great horned owl adults were also observed in the southwest portion of the study area in the dense cottonwood/spruce forest along the Snake River bottom. It is possible that these individuals did not nest, nested just outside the study area and foraged on the study area, or, we failed to locate the nest.

Reoccupancy rates-Reoccupancy rates were highest for the American Kestrel (Table 2). Thirty-six percent of the kestrel nesting areas used in 1947 were still being used in 2001, and $73 \%$ of nesting areas used in 1987 were occupied in 2001. For all three species, the reoccupancy rate after 54 years was $27 \%$. 
Table 2. Percent of nesting areas used by raptors in 1947 and 1987 that were reoccupied in 2001, Grand Teton National Park.

\begin{tabular}{|c|c|c|c|c|c|c|}
\hline \multirow[t]{2}{*}{ Species } & \multicolumn{3}{|c|}{1947} & \multicolumn{3}{|c|}{1987} \\
\hline & $\begin{array}{l}\text { Sample } \\
\text { size }\end{array}$ & $\begin{array}{l}\text { Reoccupied } \\
\text { in } 2001\end{array}$ & $\begin{array}{c}\% \\
\text { reoccupied }\end{array}$ & $\begin{array}{c}\text { Sample } \\
\text { size }\end{array}$ & $\begin{array}{l}\text { Reoccupied } \\
\text { in } 2001\end{array}$ & $\begin{array}{c}\% \\
\text { reoccupied }\end{array}$ \\
\hline Kestrel & 11 & 4 & 36 & 11 & 8 & 73 \\
\hline $\begin{array}{l}\text { Red- } \\
\text { tailed } \\
\text { hawk }\end{array}$ & 12 & 2 & 16 & 9 & 3 & 33 \\
\hline $\begin{array}{l}\text { Common } \\
\text { raven }\end{array}$ & 3 & 1 & 33 & 10 & 5 & 50 \\
\hline Total & 26 & 7 & 27 & 30 & 16 & 53 \\
\hline
\end{tabular}

Nesting Densities-Although the constituent species within the study area has changed considerably since 1947, the nesting density of all raptors changed little $\left(3.8 / \mathrm{mi}^{2}\right.$ in $1947 \mathrm{vs} 3.4 / \mathrm{mi}^{2}$ 2001), and the combined number of buteos and ravens remained the same (Appendix 3). American kestrels and common ravens showed the highest density ( 0.48 and $0.41 / \mathrm{km}^{2}$ respectively), more than twice the density for Red-tailed hawks $\left(0.16 / \mathrm{km}^{2}\right)$ (Fig 2).

Ground squirrel density-Ground squirrel density decreased in colony $\mathrm{O} 2$ from 48 squirrels/ha in 2000 to 20 squirrels/ha in 2001, and decreased in colony S4 from 18 squirrels/ha in 2000 to nine squirrels/ha in 2001 (Wigglesworth, 2001 for detailed results and discussion).

Weather-The monthly mean temperatures for 2001 were warmer than long-term monthly averages. March temperatures have shown a slight upward trend over the past 50 years. Mean temperature during May 2001 (incubation period for RTHA) was the fifth highest in 50 years. Although there appears to be a slight cooling trend during July, no other detectable trend exists for other monthly temperatures. July precipitation has shown a $\mathrm{n}$ upward trend during the past 42 years. However, June and July precipitation during the past two years has been roughly $60 \%$ below normal.

Human disturbance-From February 15 to August 15, we encountered 109 individuals in the backcountry of our study area (hikers, runners, anglers, horseback riders, or federal employees). Although not included in this count, rock climbers were present at the northwest area of Blacktail Butte on a daily basis during the months of July and August (R. Jackson, GTNP, pers. com.). Although no records were kept in 1947, (Craighead and Craighead 1956) they rarely if ever encountered people during the course of the study (J. Craighead, pers. comm.). Since 1963, there has been a $97 \%$ increase in the number of people using the Jackson Hole airport. The number of commercial plane landings has remained relatively constant over the past 10 years. Since 1972, the number of passengers on private and commercial raft trips on the Snake River through the study area has steadily increased. However, a significant decline in passengers has occurred over the past five years (1997 to 2001) when compared to the period 1991-1996 (mean=85582 vs. 106766 respectively, $\mathrm{p}<0.001, \mathrm{t}=7.32$ ). The highest number of passengers was 127,000 recorded in 1986. There were significantly fewer visitors to the Moose Visitor Center in 2001 compared to 2000 during the months of April through August (mean=43643 vs. 30339, respectively, $\mathrm{p}=0.02, \mathrm{t}=3.6$ ). The Moose Visitor Center is situated near the center of our study area within the Snake River riparian corridor, and is approximately $0.5 \mathrm{~km}$ from the west slopes of Blacktail Buttte.

Survey effort-We hiked a total of $663 \mathrm{~km}$ in $407 \mathrm{~h}$ (mean=21 km hiked $/ \mathrm{km}^{2}$ of study area, 1.1 $\mathrm{km} / \mathrm{h}$ ) in search of raptor nests. We conducted $205 \mathrm{~h}$ of observation from different locations within the study area (Table 3 ).

Table 3. Raptor nest survey effort in a $31.1 \mathrm{~km}^{2}$ study area, GTNP, 2001. Distances were calculated using a GPS tracking function.

\begin{tabular}{cccc}
\hline \hline Month & $\begin{array}{c}\text { Distance } \\
(\mathrm{km}) \\
\text { surveyed }^{\mathrm{a}}\end{array}$ & $\begin{array}{c}\text { Hours } \\
\text { of } \\
\text { survey }^{\mathrm{b}}\end{array}$ & $\begin{array}{c}\text { Hours } \\
\text { observation }^{\mathrm{c}}\end{array}$ \\
\hline March & 61.5 & 31 & 52 \\
April & 84.5 & 43.8 & 41 \\
May & 197.3 & 126.9 & 38 \\
June & 164.2 & 111.3 & 37 \\
July & 119.1 & 71 & 26 \\
August & 36.6 & 23.7 & 11 \\
Total & 663.2 & 407.7 & 205 \\
\hline
\end{tabular}

${ }^{a}$ foot surveys only, (DC, RS combined per month).

${ }^{\mathrm{b}}$ foot surveys only

${ }^{c}$ observations made from vehicles and/or other locations within the study area.

\section{$\uparrow \quad$ DISCUSSION}

Cause of reproductive variation-Our findings showed that productivity for four of the seven species we located on the study area was comparable to other studies. However, reproductive success on our study area was the lowest reported for a Red-tailed hawk population ( 0.20 young/occupied 
nest). In addition, we observed four of the five RTHA pairs occupy and defend a territory, deliver sticks to the nest, and copulate, but we did not observe incubation behavior for the typical duration expected for this species. We did not determine if eggs were laid in either of these nests. All four pairs remained on their territory throughout the breeding season. We suspect a number of factors may have contributed to this low reproductive rate, including: 1) the unpredictability of climatic events in the spring could generate unstable prey population dynamics. Ground squirrels and mice comprise $75 \%$ and $65 \%$ of Red-tailed hawk and Swainson's hawk diets, respectively (Craighead and Craighead 1956). We suspect that where ground squirrels are principal raptor prey their relative proportion in raptor diets is a good indicator of rodent availability. It appears that May and June is probably the most stressful time for ground squirrels in our study area. As the snow melts, these animals emerge from underground dens and depend on green vegetation. Females come into estrus and breed within a few days of emergence and young emerge roughly three to four weeks later (Reiger 1996). Thus, it appears that the onset of reproduction and, food availability during the time when young emerge is closely linked with ground moisture in the spring and precipitation during May and June, respectively. As indicated earlier, precipitation during 2001 was one of the lowest recorded in the past 51 years, and grass and forb vegetation appeared dry by the middle of June. In addition, estimates of ground squirrel densities were also considerably lower than in year 2000. Further, the time of emergence of y oung squirrels (late May and early June) also coincided with time of egg hatching for Red-tailed Hawks, and increased foraging effort by adults on our study area. Thus, low rodent populations may partially explain the observed low productivity and/or low abundance of raptors such as buteos and owls that coexist,and overlap on our study area.

No long-term data are available on population dynamics of small rodents in the study area. Consequently, we do not know if smallmammal prey populations are in a decline, However, Steenhof and Kochert (1985) showed that during prey shortages in southwest Idaho, two hawk species that shared foraging ranges had higher diet overlaps and converged upon one or two prey items than pairs with unshared ranges. They suggested the mechanism behind the shift to greater diet overlap in context to opportunistic feeding on the most abundant mammal prey, without implicating interspecific competition. These results differ from what is predicted where interspecific competition favors resource partitioning (food niche separation) during periods of scarce food. (see Steenhof and Kochert 1985, for review of studies).

We should note, however, that the relationship expressed between precipitation and vegetation growth on the one hand, and raptor population dynamics on the other is correlational and not necessarily causative. Any interpretation of the correlation between climate and raptor demographic features can only be speculative without further investigation. Numerous studies of raptors have emphasized the close relationship between raptor reproduction and the densities of principal prey species (e.g. Woffinden and Murphy 1977, Adamcik et al. 1978, Korpamaki 1992).

Second, cattle grazing was intense on the southern and eastern portion of the study area between Mormon row and Blacktail Butte throughout the summer months. The combined effect of a large number of cattle confined to a relatively small area and low spring precipitation resulted in the near complete loss of ground vegetation by mid-June over approximately $30 \%$ of the study area.

Conclusions and Recommendations-There are few, if any, locations in the western U.S. where raptor populations have been monitored over such a period of time. The caveat, however, is that while long term measurement of raptor population dynamics on the Blacktail Butte study area can identify patterns of change in species distribution and diversity, those measurements do not produce direct cause-and-effect relationships. We believe that pattern and cause of changes in raptor diversity and abundance we observed are of primary interest in basic ecological research. Thus, comprehensive, long-term observational research, when coupled with manipulative experiments can yield an integrated understanding of cause-and-effect that may directly inform management and policy decisions.

Future research projects we recommend on raptors in order of feasibility based on available funding include: 1) a complete analyses of all raptor censuses conducted on the Moose study area, 2) community level habitat studies of diurnal and nocturnal raptors on the study area to determine niche partitioning and competitive interactions and potential effects of habitat changes on raptors, 3) analysis of foraging habitat by radio-tracking adults of select members of each raptor guild on the study area, 4) radio-tracking study of adult and juvenile dispersal to identify habitats which the population uses for migration and over-wintering, and 5) future 
study designs could include coupling long-term measurements with manipulative experiments (e.g. experimental removal of ravens) that can help document patterns, determine mechanisms, and possibly generate new theories and testable hypotheses.

\section{ACKNOWLEDGEMENTS}

We wish to acknowledge the support and assistance of GTNP Wildlife Biologist Steve Cain. We especially thank field volunteer Bryan Bedrosian who surveyed many hundreds of acres in an enthusiastic manner. We are also grateful to T. Berg, D. Carpenter, S. Craighead, M. Creel, B. Kirkland, N. McClellend, R. Wigglesworth, and D. Wile for their assistance with field efforts.

\section{LITERATURE CITED}

Adamcik, R. S., A. W. Todd, L. B. Keith. 1978. Demographic and dietary responses of great horned owls during a snowshoe hare decline. Canadian Field-Naturalist. 92:156166.

Brawn, J. D., S. K. Robinson, D. E. Stotz, and W. D. Robinson. 1998. Research needs for the conservation of neotropical birds. In Avain Conservation, research and management. J. M. Marzluff and R. Sallabanks, eds. Island Press, Washington, D.C. 563pp.

Chalfoun, A. D. 2000. The distribution and abundance of Uinta ground squirrels, Spermaophilus armatus, in GTNP, Wyoming. Unpublished report, Beringia South.

Craighead, J. J., and F. C. Craighead. 1956. Hawks, Owls and Wildlife. Stackpole Co., Harrisburg, Pennsylvania, and Wildlife Management Inst., Washington, D.C. 443pp.

Craighead, F. C., and D. P. Mindell. 1981. Nesting raptors in western Wyoming, 1947 and 1975. J. Wildl. Manage. 45:865-872.
Craighead, F. L., F.C. Craighead Jr., and J.W. Tischendorf. 1987. Stability of raptor communities over time. Craighead Environmental Research Institute, Moose, Wy.

Dunk, J. R., R. N. Smith, and S. L. Cain. 1997. Nest-site selection and reproductive success in common ravens. Auk:116-120.

ESRI. 1996. Arcview, version 3.1. Environmental Systems Research Institute. Redlands, CA. USA.

Korpamaki, E. 1992. Diet composition, prey choice, and breeding success of long-eared owls: effects of multiannual fluctuations in food abundance. Canadian J. Zoology. 70:23732381.

Latta, S.C. and M.E. Baltz. 1997. Population limitations in Neotropical migratory birds: Comments on Rappole and McDonald (1994). Auk 114:754-762.

Lehman, R. N., B. Carpenter, K. Steenhof, and M. N. Kochert. 1998. Assessing relative abundance and reproductive success of shrubsteppe raptors. J. Field Ornithology. 69:244-256.

Martin, T.E., and D.M. Finch. 1995. Ecology and management of neotropical migratory birds: A synthesis and review of critical issues, ed. $\mathrm{T}$ Martin and D. Finch. Oxford University Press, New York.

Parker, J. W. 1972. A mirror pole device for examining high nests. Bird-Banding. 43:216-218.

Postupalski, S. 1974. Raptor reproductive success: some problems with methods, criteria, and terminology. Pages 21-31 in Hamerstrom, F. N. Jr., Harrell, B. and Olendorff, R. eds. Management of raptors. Proc. of the Conf. on Raptor Conservation Techniques, Fort Collins, CO. Raptor Research Found. Vermillion, S. Dakota. 146pp. 
Rappole, J. H. 1995. The ecology of migrant birds. A neotropical perspective. Smithsonian Institute Press, Washington, D.C. 269pp.

Reiger, J. F. 1996. Body size, litter size, timing of reproduction, and juvenile survival in the Uinta ground squirrel, Spermophilus armatus. Oecologia. 107:463-468.

Steenhof, K. and M. N. Kochert. 1985. Dietary shifts of sympatric buteos during a prey decline. Oecologia. 66:6-16.
Wigglesworth, R. 2001. Uinta ground squirrel surveys, 2001. Unpublished report, Beringia South.

Woffinden, N. D. and J. R. Murphy. 1977. Population dynamics of the ferruginous hawk during a prey decline. Great Basin Naturlaist. 37:411-425. 
Appendix 1. Nest tree type, tree condition and total number of raptor nests in Grand Teton National Park, 2001.

$\mathrm{N}=41$.

\begin{tabular}{|c|c|c|c|c|c|c|c|c|c|}
\hline $\begin{array}{l}\text { Nest tree } \\
\text { species }\end{array}$ & $\begin{array}{l}\text { Kestrel } \\
\text { (cavity) }\end{array}$ & $\begin{array}{l}\text { Red- } \\
\text { tailed } \\
\text { hawk }\end{array}$ & $\begin{array}{l}\text { Swainson } \\
\text { hawk }\end{array}$ & $\begin{array}{l}\text { Cooper's } \\
\text { hawk }\end{array}$ & $\begin{array}{l}\text { Sharp- } \\
\text { shinned } \\
\text { hawk }\end{array}$ & $\begin{array}{l}\text { Bald } \\
\text { eagle }\end{array}$ & $\begin{array}{l}\text { Great } \\
\text { horned } \\
\text { owl }\end{array}$ & Raven & $\begin{array}{c}\text { Totals } \\
(\%)\end{array}$ \\
\hline \multicolumn{10}{|c|}{ Cottonwood (Populus angustifolia) } \\
\hline Live & 6 & 1 & 1 & 0 & 0 & 0 & 0 & 4 & 12 \\
\hline Snag & 2 & 0 & 0 & 0 & 0 & 0 & 0 & 0 & 2 \\
\hline Total & 8 & 1 & 1 & 0 & 0 & 0 & 0 & 4 & $14(34.1)$ \\
\hline \multicolumn{10}{|c|}{ Aspen (Populus tremuloides) } \\
\hline Live & 1 & 0 & 0 & 0 & 0 & 0 & 0 & 2 & 3 \\
\hline Snag & 3 & 0 & 0 & 0 & 0 & 0 & 0 & 0 & 3 \\
\hline Total & 4 & 0 & 0 & 0 & 0 & 0 & 0 & 2 & $6(14.6)$ \\
\hline \multicolumn{10}{|c|}{ Douglas fir (Pseudotsuga menzezii) } \\
\hline Live & 0 & 1 & 0 & 0 & 0 & 0 & 0 & 4 & 5 \\
\hline Snag & 1 & 0 & 0 & 0 & 0 & 0 & 0 & 0 & 1 \\
\hline Total & 1 & 1 & 0 & 0 & 0 & 0 & 0 & 4 & $6(14.6)$ \\
\hline \multicolumn{10}{|c|}{ Blue spruce (Picea pungens) } \\
\hline Live & 0 & 2 & 0 & 1 & 1 & 1 & 0 & 3 & 8 \\
\hline Snag & 0 & 0 & 0 & 0 & 0 & 0 & 0 & 0 & 0 \\
\hline Total & 0 & 2 & 0 & 1 & 1 & 1 & 0 & 3 & $8(19.5)$ \\
\hline \multicolumn{10}{|l|}{ Nest box } \\
\hline & 1 & 0 & 0 & 0 & 0 & 0 & 0 & 0 & $1(2.4)$ \\
\hline \multicolumn{10}{|l|}{ Unknown } \\
\hline & 1 & 1 & 1 & 0 & 0 & 0 & 3 & 0 & $6(14.6)$ \\
\hline $\begin{array}{l}\text { Total } \\
\text { (\% total) }\end{array}$ & $\begin{array}{c}15 \\
(36.5)\end{array}$ & $\begin{array}{c}5 \\
(12.1)\end{array}$ & $\begin{array}{c}2 \\
(4.8)\end{array}$ & $\begin{array}{c}1 \\
(2.4)\end{array}$ & $\begin{array}{c}1 \\
(2.4)\end{array}$ & $\begin{array}{c}1 \\
(2.4)\end{array}$ & $\begin{array}{c}3 \\
(7.3)\end{array}$ & $\begin{array}{c}13 \\
(31.7)\end{array}$ & 41 \\
\hline
\end{tabular}


Appendix 2. Nest name, number of young birds fledged and fledging dates for raptors found in a GTNP study area, 2001.

\begin{tabular}{lr}
\hline Species & \# fle \\
American Kestrel & 2 \\
McReynold's & 2 \\
Moulton & 2 \\
BTBSE1 & 3 \\
BTBSW & 3 \\
Ditch Confluence & 0 \\
Terrace & 2 \\
McCabeN & 2 \\
BTBS1 & 2 \\
BTBS2 & 2 \\
BTBNW1 & 2 \\
4lazyF & 1 \\
Ditch Creek SE & 2 \\
Ditch Creek SW & 3 \\
BTBE * & 2 \\
Choinard & \\
Mean &
\end{tabular}

fledge date ${ }^{\mathrm{a}}$

Bald Eagle

Riverhouse *

18-Jul

2 24-Jul

2

20-Jul

3 22-Jul

3

25-Jul

0

fail

24-Jul

20-Jul

19-Jul

26-Jul

26-Jul

27-Jul

29-Jul

29-Jul

2 26-Jul

Cooper's hawk

Murie Ranch

\section{Common raven}

McReynolds

East McReynold

BTBS

Knob

BTBSW1

BTBSW2

BTBSW3

BTBSE

Headgate

Ditch Confluence

Hart1

Mormon row $\mathrm{S}$

Mormon row $\mathrm{N}$

Mean

3-Aug

a fledge dates are estimates $+/-3$ days.

fail

15-Jun

19-Jun

18-Jun

16-Jun

14-Jun

fail

21-Jun

fail

24-Jun

12-Jun

fail

fail

17 July 
Appendix 2 (con't)

Species

\# fledge

Fledge date

Red-tailed hawk

BTBN

0

fail

BTBSW

0

fail

4-Lazy-F

0

fail

Givens

0

fail

Murie Ranch

1

5-Jul

Sharp-shinned hawk

Murie Ranch

4

31-Jul

Swainson's hawk

Moulton / Ditch

1

28-Jul

BTBS

2

23-Jul 
Appendix 3. Number of territorial raptor pairs from all previous studies conducted on the main study area, Moose, WY, 1947-2001.

\begin{tabular}{|c|c|c|c|c|c|c|c|c|}
\hline Species & 1947 & 1948 & 1975 & 1978 & 1979 & 1987 & 2001 & Totals \\
\hline Red-tailed Hawk & 12 & 11 & 7 & 5 & 7 & 9 & 5 & 56 \\
\hline Swainson's Hawk & 5 & 1 & 2 & 2 & 1 & 1 & 2 & 14 \\
\hline Kestrel & 11 & 10 & 10 & 9 & 10 & 11 & 15 & 76 \\
\hline Goshawk & 0 & 0 & 1 & 1 & 1 & 0 & 0 & 3 \\
\hline Cooper's Hawk & 1 & 1 & 2 & 0 & 0 & 0 & 1 & 5 \\
\hline $\begin{array}{l}\text { Sharp-shinned } \\
\text { Hawk }\end{array}$ & 2 & 0 & 3 & 0 & 0 & 4 & 1 & 10 \\
\hline Great Horned Owl & 4 & 4 & 3 & 3 & 3 & 4 & 3 & 24 \\
\hline Long-eared Owl & 3 & 2 & 2 & 0 & 0 & 2 & 0 & 8 \\
\hline Screech Owl & 3 & 2 & 0 & 0 & 0 & 0 & 0 & 5 \\
\hline Prairie falcon & 1 & 1 & 0 & 0 & 0 & 0 & 0 & 2 \\
\hline Osprey & 1 & 1 & 0 & 1 & 1 & 0 & 0 & 4 \\
\hline Bald Eagle & 0 & 0 & 0 & 0 & 0 & 0 & 1 & 1 \\
\hline Common Raven & 3 & 3 & 11 & 8 & 10 & 10 & 13 & 58 \\
\hline
\end{tabular}

